\title{
A REVIEW OF THE LITERATURE AND A DISCUSSION OF SILVER ARSPHENAMIN *
}

H. E. MICHELSON, M.D.

Instructor in Dermatology, University of Minnesota

AND

DAVID M. SIPERSTEIN, M.A.

Voluntary Assistant, Night Syphilis Clinic, University of Minnesota

MINNEAPOLIS

Silver arsphenamin, the latest of the arsphenamin series of drugs, is now on the market, and is being used in America. There is no English literature to guide one in determining its qualities. Our communication is an effort to review the literature on silver arsphenamin and to draw conclusions therefrom.

Silver arsphenamin was suggested by Ehrlich, whose untimely death cut short his researches, which were continued by Kolle who finally elaborated silver arsphenamin. This drug was first used clinically in March, 1918.

$\mathrm{Kolle}^{1}{ }^{1}$ in 1918, in the first of a series of articles, gives the following table which shows that silver arsphenamin had a more profound effect on experimental syphilis than any of the other members of the arsphenamin group. He concludes from his work that silver when combined with the arsphenamin molecule forms a combination which has a greater spirocheticidal action than other combinations with which he worked.

In his second article, published in $1919 \mathrm{Kolle}^{2}$ discusses at length the chemical properties of the drug and concludes that silver arsphenamin acts on the syphilitic process in a two-fold manner: The arsphenamin molecule exerts its well-known spirocheticidal effect, while the presence of the silver radical seems to inhibit the growth of the spirochetes. Therefore, he says, silver arsphenamin acts in combination.

Kolle, ${ }^{3}$ in 1920 , reviewed the clinical results of various observers.

*Read before The Clinical Club, Minneapolis, April 10, 1921.

* From the Department of Dermatology and Syphilology, University of Minnesota, Minneapolis.

1. Kolle, W.: Experimentelle Studien zu Ehrlich's Salvarsan therapie der Spirochätenkrankheiten und ïber neue Salvarsanpräparate, Deutsch. med. Wchnschr. Nos. 43 and 44, p. 1177, Oct. 24, 1918 and Oct. 31, 1918.

2. Kolle, W., and Ritz, H.: Experimentelle Untersuchungen über die Wirkung des Silbers und seiner Verbindungen auf die Kaninchensyphilis, mit besonderer Berücksichtigung des Silbersalversans, Deutsch. med. Wchnschr. No. 18, 1919.

3. Kolle, W.: Weitere Mitteilungen über Silbersalvarsan, Deutsch. med. Wchnschr. No. 2, 1920. 
Fabry, ${ }^{4}$ in 1918, used silver arsphenamin on 100 patients, all of whom had active clinical manifestations of syphilis. At first he hospitalized his patients, but later he used the drug on ambulatory cases. He dissolved $0.2 \mathrm{gm}$. in 5 c.c. of sterile distilled water, and later 0.3 gm. in 6 or 7 c.c. using a 10 c.c. syringe. He found that infiltration of the subcutaneous tissues with a solution of this concentration was very painful. He concluded that 0.2 or $0.3 \mathrm{gm}$. of silver arsphenamin is sufficient to cause the disappearance of spirochetes from the lesions; that sclerosae and condylomas disappear, at least as rapidly as with old arsphenamin, and that large tertiary ulcers involute with great rapidity. No bad effects were noticed. There was a slight febrile reaction in "secondary syphilis" after the first injection. He noticed urticarial reactions in some cases, which disappeared in a few days. He did not repeat injections until all signs of dermal reaction had

Effect of Various Drugs on Experimental Syphilis

\begin{tabular}{lcc}
\hline \multicolumn{1}{c}{ Drug } & Therapeutic Dose & $\begin{array}{c}\text { Spirochetes } \\
\text { Disappeared After }\end{array}$ \\
Old Arsphenamin & $0.01 \mathrm{gm}$. per kilo & 72 hours \\
Neo-Arsphenamin & $0.015 \mathrm{gm}$. per kilo & 48 hours \\
Copper Arsphenamin & $0.004 \mathrm{gm}$. per kilo & 96 hours \\
Gold Arsphenamin & $0.005 \mathrm{gm}$. per kilo & 48 hours \\
Platinum Arsphenamin & $0.005 \mathrm{gm}$. per kilo & 48 hours \\
Silver Arsphenamin & $0.004 \mathrm{gm}$. per kilo & 24 hours \\
\hline
\end{tabular}

subsided. The Wassermann reaction did not revert to negative as quickly as one would expect from a drug whose clinical action was so rapid and intense.

In 1919, Fabry, ${ }^{5}$ after further extensive use of silver arsphenamin, stated that he believed it to be the most active of the arsphenamin products on clinical manifestations and for destruction of spirochetes. At the same time, the necessary dosage is decidedly smaller than that of any of the other products. In order to determine the tolerance for the drug, he employed heroic treatment using from 0.2 to $0.3 \mathrm{gm}$. at three to four day intervals, giving ten to twenty doses. Later he decided that he obtained the same clinical results with a longer interval - five to seven days. With regard to the action on the Wassermann reaction: It became negative in many cases, but in active secondary syphilis it often remained positive. For this reason, he recommended

4. Fabry, J.: Ueber die Behandlung der Syphilis mit Silbersalvarsan, Deutsch. med. Wchnschr. No. 44, p. 1216-1218, Oct. 31, 1918.

5. Fabry, J.: Ueber Behandlung der Syphilis mit Silbersalvarsan, Deutsch. med. Wchnschr., No. 49, p. 1358-60, Dec. 4, 1919. 
that a few neo-arsphenamin and mercury injections be given following a course of silver arsphenamin. He reported a case of universal weeping dermatitis after two injections ( 0.1 and $0.2 \mathrm{gm}$.); the patient recovered promptly.

Galewsky, ${ }^{6}$ in 1918, gave 700 injections of silver arsphenamin to 165 patients. The injections were given after working hours on ambulatory patients. He considers silver arsphenamin a powerful drug whose therapeutic dose is one-third that of old arsphenamin, but whose toxic dose is two and one-half times as great as neo-arsphenamin. He always used it in combination with mercury, giving ten to fourteen mercury and four to eight ( 0.1 to $0.15 \mathrm{gm}$.) silver arsphenamin injections for the first course, and six to eight mercury and two to four silver arsphenamin injections for the subsequent courses. He gave weekly or biweekly injections, and noted no ill effects. The Wassermann reaction became negative as often and as early as with any other arsphenamin preparation.

Galewsky, ${ }^{7}$ in 1920 , after giving 2,000 injections, decided that the best average dose for women was $0.2 \mathrm{gm}$. and for men $0.25 \mathrm{gm}$., eight to fifteen injections constituting a course. Results were more rapid than with old arsphenamin. Spirochetes could not be found from twenty-four to forty-eight hours after the first dose. Sclerosae and roseolae disappear in a few days. The Wassermann reaction becomes negative very often after three weeks or after 1.5 to $2.0 \mathrm{gm}$. of the drug have been given, and he emphatically states that it reverts to negative more rapidly than with any other arsphenamin preparation. He concludes that silver arsphenamin takes the first place in the treatment of early syphilis and in effecting abortive "cures." In the treatment of early tabes, vascular and cerebral syphilis, special care must be exercised in using silver arsphenamin. He believed that there are fewer untoward effects with silver arsphenamin than with any of the other arsenical preparations. Finally, he belives the time has come to decide definitely in which group of cases a pure arsphenamin treatment should be instituted, and whether it is not advisable to give up the combined mercury and arsphenamin courses.

Gennerich, ${ }^{8}$ in 1918, gave 1,000 injections of silver arsphenamin to 100 patients. Small doses, from 0.1 to $0.2 \mathrm{gm}$., were given at four day intervals until four doses had been given; then the interval was lengthened to six or seven days until the course of five to ten injections

6. Galewsky, E.: Ueber Silbersalvarsannatrium, Deutsch. med. Wchnschr. No. 48, pp. 1326-1327, Nov. 28, 1918.

7. Galewsky, E.: Zwei Yahre Silbersalvarsan-Therapie, München. med. Wchnschr. Jan. 30, 1920.

8. Gennerich: Ueber Silbersalvarsan, Deutsch. med. Wchnschr. No. 45, pp. 1243-1244, Nov. 7, 1918. 
had been completed. He believes that the drug is the most powerful and the safest of the arsphenamin preparations, having only four minor reactions in his entire series. Furthermore, he believes that the drug is especially suitable for the abortive "cure of primary Wassermann negative cases." A patient with this type of case he treated for from two and one-half to three weeks after first excising the chancre. He thinks courses of silver arsphenamin are more efficient in fresh secondary syphilis than courses of any other arsphenamin product or than courses of arsphenamin combined with mercury.

In 1919 , Gennerich ${ }^{9}$ again reported on the results of 3,500 injections of silver arsphenamin on 315 patients. As the war had caused a scarcity of silver arsphenamin, some of his courses had to be supplemented with injections of neo-arsphenamin. In these cases he did not give more than seven injections of neo-arsphenamin because of the danger of icterus. In 3,500 injections of silver arsphenamin, he saw onily one case of mild icterus.

Hahn, ${ }^{10}$ in 1918, gave 1,000 injections of silver arsphenamin to eighty-two patients. He treated both recent and old cases of syphilis, and was in accord with the opinion of other observers that cutaneous and mucous membrane lesions disappeared rapidly. His observations on old cases of syphilis are especially interesting. He noted that in a -series of Wassermann-fast cases, the reaction soon became negative and remained negative for the length of the period of observation. He reports no severe reactions, and states his hope that this drug will eliminate the need of mercury in the treatment of syphilis.

Hahn, ${ }^{11}$ in 1920 , reported his further observations on silver arsphenamin, having given 4,000 injections to 300 patients. Hel standardized his technic beginning with $0.1 \mathrm{gm}$. and gradually increasing the dosage to $0.3 \mathrm{gm}$. given biweekly, in from 10 to 20 c.c. of sterile distilled water. The Wassermann reaction always became negative after twelve injections in fresh cases and almost always in old cases. He concluded that the action of silver arsphenamin on all the manifestations of syphilis in all its stages is excellent and that it acts rapidly and with certainty.

Hugo Miller, ${ }^{12}$ in 1918, gave 1,000 injections of silver arsphenamin to 170 patients. He thinks that silver arsphenamin sterilizes the human

9. Gennerich: Kriegserfahrungen in der Luesbehandlung, unter besonderer Berucksichtigung des Silbersalvarsans, Berl. klin. Wchnschr., p. 769, Oct. 18, 1919 ; No. 34, p. 803, Oct. 25, 1919.

10. Hahn, F.: Ueber Silbersalvarsan, Deutsch. med. Wchnschr. No. 50, pp. 1385-1386, Dec 12, 1918.

11. Hahn, F.: Silbersalvarsan in der Syphilistherapie, Deutsch. med. Wchnschr. No. 4, pp. 92-93, Jan. 22, 1920.

12. Miller, Hugo: Silbersalvarsannatrium-Behandlung der Syphilis, Deutsch. med. Wchnschr. No. 51, pp. 1415-1416, Dec. 19, 1918. 
organism infected with syphilis more thoroughly than any other drug which we have. He also thinks that the effect on the Wassermann reaction is more noticeable than with neo-arsphenamin. Dermal reaction can be avoided by slow injection with great dilution.

Sellei, ${ }^{13}$ in 1918 , observed that secondary lesions were not immediately affected, but that a few days after injection there was rapid involution. In a case of nephritis with syphilis he gave the drug without ill effects. Sellei, ${ }^{14}$ in 1920 , found that dosage of $0.04,0.06,0.08$ and $0.1 \mathrm{gm}$. gave the same results as $0.1,0.15,0.2$ and $0.3 \mathrm{gm}$., and affected the Wassermann reaction sooner. He believes the drug is particularly suited for use in syphilis of the nervous system.

Weichbrodt, ${ }^{15}$ in 1918, used the drug in eighteen cases of paresis and tabes. He thought the drug suitable, but drew no conclusions. There was no marked effect on paresis.

Weichbrodt, ${ }^{16}$ in 1919 , noted that three months after the spinal fluid had been made negative with silver arsphenamin it became positive, and he tried in vain to revert it to negative. His final conclusion was that silver arsphenamin is the drug of choice in paresis, although it gives no permanent benefit to the patient.

Hauck, ${ }^{17}$ in 1919 , reported on 600 injections into sixty patients in all stages of syphilis. He started with $0.1 \mathrm{gm}$., gradually increasing the dose to $0.25 \mathrm{gm}$. for women and $0.3 \mathrm{gm}$. for men. He gave from ten to twelve doses in a course, and did not use mercury in combination. One injection of $0.1 \mathrm{gm}$. was sufficient to cause disappearance of mucous patches. The effect of a course of silver arsphenamin was particularly striking in its effect on the lymph node enlargement. The adenitis disappeared rapidly. He found definite improvement in tabes after twelve injections of $0.1 \mathrm{gm}$. There were no severe reactions, exanthems or icteri, and he concluded that silver arsphenamin is a great advance in the therapy of syphilis.

Kerl, ${ }^{18}$ in 1919 , used the drug in concentrated solution, $0.1 \mathrm{gm}$. in 6 c.c. of water, and concluded that the same result can be obtained with

13. Sellei, J.: Das Silbersalvarsan, Deutsch. med. Wchnschr. No. 45, pp. 1247-1248, Nov. 7, 1918.

14. Sellei, J.: Weitere Erfahrungen mit Silbersalvarsan, Med. Klin. No. 12. Mar. 21, 1920.

15. Weichbrodt, R.: Silbersalvarsannatrium und Sulfoxylatpräparat (No. 1495 ) in der Paralyse-therapie, Deutsch. med. Wchnschr. No. 44, pp. 1216-1217, Oct. 31, 1918.

16. Weichbrodt, R.: Weitere therapeutische Versuehe bei Paralyse, Deutsch. med. Wchnschr. No. 13, pp. 357-358, Mar. 27, 1919.

17. Hauck, L.: Die Behandlung der Syphilis mit Silbersalvarsannatrium, Med. Klin. No. 24, pp. 581-582, Jan. 15, 1919.

18. Kerl, W.: Ueber Silbersalvarsan, Wien. klin. Wchnschr., 1919, No. 17, pp. $446-447$. 
0.1 to $0.2 \mathrm{gm}$. of silver arsphenamin that one can obtain with $0.4 \mathrm{gm}$. of old arsphenamin.

Knopf and Sinn, ${ }^{19}$ in 1919, treated eighty-two patients with active manifestations. They treated fifty-nine with silver arsphenamin only; in twenty-three cases they combined its use with mercury. Their objections to the drug were:

1. It is hard to see undissolved particles.

2. It is more difficult to determine an oxidized product than in the case of lighter colored arsphenamin.

3. It is hard to see blood in the syringe when aspirating after venipuncture.

Their technic was to administer $0.1 \mathrm{gm}$. on the first day, $0.2 \mathrm{gm}$. on the third or fifth day, and after that $0.3 \mathrm{gm}$. every fourth day for ten or twelve injections. They encountered angioneurotic reactions when they used concentrated ( 5 to 10 c.c.) solutions. These disappeared on using 15 to 20 c.c. of dilutant and making very slow injections. They concluded that the effect on the Wassermann reaction is not as great as would be expected in view of the intense action on clinical manifestations.

Kreibich ${ }^{20}$ in 1919 , gave 400 injections to 100 patients, using 0.2 to $0.3 \mathrm{gm}$. in two to four doses in a course. He gave $0.2 \mathrm{gm}$. to a weak 8-year old boy twice within ten days with beneficial effect and no reaction. He used a 10 c.c. dilution, noting only mild reactions. On active lesions, $0.3 \mathrm{gm}$. of silver arsphenamin gives about the same result as $0.4 \mathrm{gm}$. of old arsphenamin. Spirochetes begin to disappear in six hours, and are all dead (in the dark field) in twenty-four hours. Considering the arsenic content, he believes silver arsphenamin is more desirable than old arsphenamin.

Sinn, ${ }^{21}$ in 1919, reported a fatal case of hemorrhagic encephalitis in a man 21 years of age with florid secondary syphilis, who received three doses of silver arsphenamin. The first dose consisted of $0.15 \mathrm{gm}$.; thrẹe days later he received $0.25 \mathrm{gm}$., and four days later $0.25 \mathrm{gm}$. $\mathrm{He}$ also received seven injections of mercury and one injection of mercury salicylate. Two days after the last silver arsphenamin injection, he became unconscious and died three and one-half days later, in spite of all efforts.

19. Knopf, W., and Sinn, O.: Ueber Silbersalvarsan nebst Bemerkungen über Konzentrierte Altsalvarsan-einspritzungen, Deutsch. med. Wchnschr. No. 19, pp. 517-518, May 8, 1919. 1919.

20. Kreibich, C.: Ueber Silbersalvarsannatrium, Med. Klin. No. 7, Feb. 16,

21. Sinn, O.: Ueber Neurorezidive nache reiner. Salvarsan und Silbersalvarsanbehandlung, München. med. Wchnschr. No. 43, pp. 1228-1229, Oct. 24, 1919. 
Lenzmann, ${ }^{22}$ in 1919, gave 250 injections of silver arsphenamin. He used a more dilute solution than most of the observers, 0.1 to 0.25 gm. in 20 to 40 c.c. He decided that the drug was suitable for use, and was well borne and less toxic than the other members of the arsphenamin group. The technic of injection, he thought was more difficult because of the color of the solution. The action on spirochetes was rapid. The drug was well borne by children. He had had reactions in two patients which lasted for a few days; they were characterized by substernal pain and stridulous breathing and a croupous cough. Both patients recovered. Concerning the effect on the Wassermann reaction, he thought it was too early to make a definite conclusion.

Lenzmann, ${ }^{23}$ in 1919 , used silver arsphenamin in a case of aortitis, but made no special comment on its value in this type of syphilitic involvement.

Levy-Lenz, ${ }^{24}$ in 1919 , gave seventy injections of silver arsphenamin. $\mathrm{He}$ had no severe reactions. He used a concentrated solution, $0.1 \mathrm{gm}$. in 3 c.c. of sterile distilled water, and he did not believe that slow injection was essential, or that the darkness of the fluid made injection more difficult, for aspiration when the needle was paravenous gave air bubbles, and when intravenous the volume of fluid in the syringe increased.

Von Notthaft, ${ }^{2 \pi}$ in 1919 , thought that the drug is the equal of old arsphenamin, but insisted on dilution and slow injection using 120 c.c. of water and a gravity apparatus. He obtained angioneurotic symptoms when he used concentrated solutions. He did not think it advis- . able to use silver arsphenamin simultaneously with mercury. He had given silver arsphenamin steadily for a period of six months and even longer without ill effect, and he believed that the solution is stable for at least thirty minutes.

Riecke, ${ }^{26}$ in 1919 , reported a death occurring in a man 41 years of age, who had a ten-week old case of florid syphilis. He was otherwise normal. He received $1.3 \mathrm{gm}$. of silver arsphenamin in seven injections over a period of forty-two days. After the first injection of $0.2 \mathrm{gm}$. he had fever, chills and weakness lasting several hours. The

22. Lenzmann, R.: Ueber Erfahrungen mit Silbersalvarsannatrium, Deutsch. med. Wchnschr. 45:355-357 (March 27) 1919.

23. Lenzmann, R.: Uber Aortitis luica, Ztschr. f. ärztl. Fortbild. No. 23, 1919.

24. Levy-Lenz: Meine Erfahrungen mit Silbersalvarsan, Deutsch. med. Wchnschr. 45:1440-1441 (Dec. 25) 1919.

25. Von Nothafft: Erfahrungen mit Silbersalvarsan, Deutsch. med. Wchnschr. 45:341 (Mar. 27) 1919.

26. Riecke, E.: Schwere Erscheinungen nach Silbersalvarsan in einem Falle florider Syphilis, Med. Klin. No. 14, pp. 329-330 (April 6) 1919. 
interval was five days. Headache and exaggeration of his first symptoms followed the third and fourth injections of $0.2 \mathrm{gm}$. The fifth injection of $0.15 \mathrm{gm}$. brought forth no symptoms of intolerance, but after the sixth injection of $0.15 \mathrm{gm}$. he had a facial erythema. In spite of this warning, he received a seventh injection of $0.2 \mathrm{gm}$. ten days later, which was followed by a severe generalized dermatitis and a complicating bronchopneumonia which terminated fatally. Riecke insisted that this death was due to intoxication with silver arsphenamin and that the drug alone was at fault.

Rille and Frühwald, ${ }^{2 i}$ in 1919 , gave ninety-two patients the usual dosage and remark that the drug is well tolerated. There were no ill effects, but its action on the Wassermann reaction was irregular.

Zieler, ${ }^{28}$ in 1919 , reported a case of severe generalized dermatitis following an injection of silver arsphenamin.

Buschke, ${ }^{29}$ in 1919 , observed two neurorecidives after initial courses of silver arsphenamin.

Carl Stern, ${ }^{30}$ in 1919 , gave 1,000 injections to ambulatory patients. His technic was unusual in that he dissolved the drug in a small amount of water and, after venipuncture, he aspirated considerable blood allowing the solution and the blood to mix before injection. He says that Kolle advised him that addition of serum lowered the toxicity of the drug. He also gave a few intramuscular injections which were surprisingly well borne, with very little pain.

Fritz Kalberlah, ${ }^{31}$ in 1919, treated nine patients with multiple sclerosis with good results, which he remarks may be due to the wellknown remissions in this condition.

Deutsch, ${ }^{32}$ in 1919 , observed four patients with negative Wassermann reactions in whom spirochetes were found. Each was given three doses of $0.3 \mathrm{gm}$. of silver arsphenamin at four day intervals. No further treatment was aciministered, but they were observed each month for one year, and they had neither a clinical nor a serologic relapse. In a fifth case of primary syphilis in which the Wassermann

27. Rille, J., and Frühwald, R.: Die Behandlung der Syphilis mit Silbersalvarsannatrium, München. med. Wchnschr. No. 43, p. 1226, Oct. 24, 1919.

28. Zieler: Würsburger Acrtzeabend 17 6:19, 1919. München. med. Wchnschr., No. 29, 1919.

29. Buschke: Berl. Dermat. Geo. 13 5:19; Deutsch. med. Wchnschr. 69:435, 1919.

30. Stern, C.: Die Technik der Silbersalvarsaninjektion, München. med. Wchnschr. No. 48, p. 1377, 1919.

31. Kalberlah, F.: Die Behandlung der multiple Sklerose mit Silbersalvarsannatrium, Med. Klin. No. 32, 1919.

32. Deutsch, R.: Abortivbehandlung der Syphilis mittels Silbersalvarsan, Dermat. Wchnschr. 69:1919. 
reaction was positive, he gave a total of $1.2 \mathrm{gm}$. of silver arsphenamin. The Wassermann reaction promptly became negative and remained so throughout the year of observation without further treatment.

Delbanco, ${ }^{33}$ in 1919, treated sixty ambulatory cases with good results and no marked reactions.

Hoppe, ${ }^{34}$ a neurologist, in 1919 , treated twenty patients with neurosyphilis. He gave both intravenous and intramuscular injections of silver arsphenamin. The intramuscular injections were not very painful, and the local reaction caused passed away rapidly for in a week neither physician nor patient could tell on which side the previous injection had been given.

Schönfeld and Birnbaum, ${ }^{35}$ in 1919, reported the use of silver arsphenamin for one year on sixty-seven patients, 1,000 injections being given. They concluded that its action on clinical manifestations is rapid; that silver arsphenamin surpasses neo-arsphenamin and sodium-arsphenamin; it about equals old arsphenamin and is less toxic. Its action on lymphadenitis is remarkably swift. The effect on the serology was found to be variable. Mild reactions were more frequent with silver arsphenamin than with old arsphenamin, but prolonged reactions were not encountered. In retrospect, after a year's use, they recommend that mercury still be combined in the therapy of old syphilis.

Goldberger, ${ }^{36}$ in 1919 , gave 266 injections to sixty patients. He reported no bad effects, but he believes that we should persist in the combination of mercury with arsphenamin. Since silver arsphenamin is more active than neo-arsphenamin and less toxic than old arsphenamin, Goldberger thinks that the change is very desirable, but if there is the slightest warning of intolerance, it should be discontinued at once.

Bruhns and Löwenberg, ${ }^{37}$ in 1919, reported the results of 1,000 injections on 107 patients. Spirochetes disappeared in sixteen hours after the injection of $0.1 \mathrm{gm}$. They summarize the results on the Wassermann reaction: "Fifty-five strongly positive cases at the beginning of the course, forty-nine were negative at completion." They

33. Delbanco, E.: Zum Silbersalvarsan und zur Biologie der Menschen und Kaninchensyphilis, Deutsch. med. Wchnschr. 45:150 (Feb, 6) 1919.

34. Hoppe, J.: Ueber Silbersalvarsannatrium, München. med. Wchnschr. No. 48, p. $1376,1919$.

35. Schönfeld, W., and Birnbaum, G.: Ueber Silbersalvarsannatrium mit besonderer Berücksichtigung des Verhaltens der Wassermann Reaktion. München. med. Wchnschr. No. 38, p. 1087, Sept 19, 1919.

36. Goldberger, P.: Unsere Erfahrungen mit Silbersalvarsan, Med. Klin. No. 38, 1919.

37. Bruhns, C., and Löwenberg: Ueber Silbersalvarsannatrium und die Dosierung des Salvarsans nebst Mitteilung eines Falles von Encephalitis haemorrhagica nach Neosalvarsan, Berl. klin. Wchnschr., 1919, No. 39, p. 913, No. 40, p. 948. 
observed slight exanthems and icterus frequently, but always after repeated doses, which emphasizes the necessity of giving the larger doses at longer intervals to avoid accumulative effect.

Dreyfus, ${ }^{38}$ in 1919 , reported only on purely neurologic cases. $\mathrm{He}$ had given 691 injections to sixty-three patients. His initial dose was $0.05 \mathrm{gm}$. to test the tolerance of the patient; he gradually increased the dose to $0.25 \mathrm{gm}$. given every second or third day. In his opinion, the drug is especially valuable in early cerebrospinal syphilis, the subjective symptoms disappearing rapidly and the objective symptoms receding in two to three weeks. In the majority of cases there is distinct improvement.

Dreyfus, ${ }^{39}$ in 1919 , in his second communication, dilated on the various reactions. He classifies them as follows:

1. Anaphylactic-angioneurotic syndromes. This is an immediate reaction which passes off rapidly. He did not see a severe one.

2. Fever usually follows the first injection and is probably due to "endotoxin" liberation.

3. Cutaneous manifestations are urticarial or exanthematous. Dreyfus observed only six exanthems in 1,000 injections.

4. Syncope, collapse, headache, weakness, nausea and vomiting do occur, but he believes this "shock" type of reaction is due to too large initial dosage. He has never observed any alarming or lasting symptoms following this type of reaction.

5. Icterus in his experience is negligible for he merely mentions the possibility of its occurring.

6. Thrombophlebitis- he has not seen this in his series of cases.

Nolten, ${ }^{40}$ in 1919, reported on 500 injections in fifty cases. $\mathrm{He}$ experienced no difficulties and concludes that silver arsphenamin is the most energetic and least toxic antisyphilitic remedy of the present day.

Ludwig Stern-Piper, ${ }^{41}$ in 1920, reported on the use of silver arsphenamin in multiple sclerosis. He concludes that there is some improvement which is apparently not due to the ordinary remission.

Abimelich, ${ }^{42}$ in 1920 , in a short report comments favorably on the use of the drug.

38. Dreyfus, G. L.: Silbersalvarsan bei luetischen Erkrankungen des Nervensystems, München. med. Wchnschr., No. 31, pp. 864-869, 1919.

39. Dreyfus, G. L.: Nebenwirkungen des Silbersalvarsans, Deutsch. med. Wchnschr. Nos. 47 and 48, p. 1293, Nov. 20, 1919 and Nov. 27, 1919.

40. Nolten: Silbersalvarsan, Deutsch. med. Wchnschr. No. 36, 1919.

41. Stern-Piper, Ludwig: Beitrage zur Therapie der muitiplen Sklerose mit Silbersalvarsan, München. med. Wchnschr., Aug. 20, 1920.

42. Abimelich, R.: Ueber Siibersalvarsan. Deutsch. med. Wchnschr. No. 10, pp. 267-268, Mar. 4, 1920. 
Lochte, ${ }^{43}$ in 1920, in an article entitled "Argyrie nach Zwölf Silbersalvarsan Injecktionen" relates a case of argyria (?) which he himself did not see. A representative of "Der Naturheilkunde" (nature healer) sent him the following case report which he thought should be published in order to warn his colleagues of the danger of argyria following injections of silver arsphenamin. Lochte, however, remarks that it cannot be verified that the case was argyria. The "nature healer" sent this report to Lochte:

A female, aged 31, infected in March, 1917, received seven neo-salvarsan injections (dose and method not given). All phenomena of lues completely disappeared in eight weeks. She suffered from a relapse in January, 1920, when she first consulted the "Nature Healer," who made a diagnosis of: (1) nodular syphilide of hairy scalp, (2) gummatous periostitis of right tibia, (3) ulcerating syphilide of right arm. Since he did not treat venereal disease, she was referred to a "specialist." (He does not state whether or not the specialist was a dermatologist.) In February, 1920, she returned to the "Nature Healer" with this story: She had reported to the specialist who had given her twelve injections of silver salvarsan. The first dose of $0.2 \mathrm{gm}$. was given intramuscularly. (The interval or size of subsequent doses was not given.) Five days after the first injection she noticed jaundice which lasted fourteen days. The treatments were not discontinued because the patient felt so well. On March 2, 1920, she noticed an ashen gray discoloration of the skin which rapidly increased.

There was no further observation of the patient. Lochte brings up the question of arsenical pigmentation caused by previous treatments with neo-arsphenamin and asks "What becomes of the silver after silver arsphenamin injections?"

\section{COMMENT}

After a careful survey of the literature and as a result of a limited personal use (250 ampules), we feel that we may safely state that silver arsphenamin is an efficient spirocheticide, which has a pronounced effect on the visible lesions of syphilis. It is not surprising that the effect on the Wassermann reaction is variable. The effect of all of the antisyphilitic remedies is variable in their action on this phenomenon. The personal factor must be considered; and since the same person cannot receive two drugs under precisely the same circumstances (age of infection, etc.), it is impossible to make an accurate comparison. Suffice it to say that the consensus of opinion of the many observers is that in the majority of cases of fresh syphilis a positive reaction becomes negative after the first course of from six to ten injections of silver arsphenamin.

43. Lochte: Argyrie nach Zwölf silbersalvarsan Injecktionen, Therap. Holb, Monatsh. 34:334, June 15, 1920. Since preparation of this review three American contributions have appeared. 
We note that the technic of solution and injection is perplexing to some operators. Because of the brown color of the solution, it is impossible to see undissolved particles. We have found that silver arsphenamin, being a heavy salt, immediately sinks when sprinkled on the surface of its solvent. If two beakers are used, the fluid may be gently decanted from one to the other, and when no residue is left in the bottom of the first beaker, the solution is ready for injection unless one wishes to use a filter. We encountered no difficulty in seeing the blood on aspiration after venipuncture. By using a Luer syringe with a long glass nozzle, the red blood can easily be seen passing through the lumen of the nozzle. There is considerable variation in the optimum dosage. An initial dose of from 0.05 to $0.1 \mathrm{gm}$. for a person of average weight is best-with a routine dose of from 0.2 to $0.25 \mathrm{gm}$. Many of the physicians, however, used $0.3 \mathrm{gm}$. with impunity. Solution in from 10 to 20 c.c. of water appears to be the strength of solution chosen by most of the observers. We are often warned of the necessity of making slow injections, and that the more dilute the solution the less the danger from reaction. Since Kolle advised the mixture of aspirated blood with the solution in order to reduce the toxicity (a fact which he ascertained by animal experimentation), we believe it should be the accepted technic: Dissolve the necessary dose in 10 c.c. of sterile distilled water, draw into a 20 c.c. Luer syringe, make venipuncture, aspirate about 10 c.c. of blood, and reinject the entire solution slowly. We have infiltrated 1 c.c. of such solution paravenously to note the effect. It was decidedly less painful than a like amount of sodium arsphenamin, and passed off more rapidly.

There is no difficulty in detecting an oxidized product. It is necessary to make up the solution first. The perfect product makes a rather sparkling, clear, dark brown solution. A spoiled product has a dull, muddy, grayish brown appearance.

One of the distinct advantages is the absence of the characteristic, and often nauseating, garlic-like or ether-like, odor which patients detect when they are receiving the other arsphenamins intravenously. This odor has made it impossible, or at least impracticable, to administer arsphenamin to certain patients. We administered three doses of 0.1 gm. of silver arsphenamin to such a type of patient. She made no complaint, and said she could detect no odor.

The interval of choice is from four to seven days, and the number of doses in a course varies greatly.

The majority of observers are not in favor of using silver arsphenamin and mercury simultaneously. In our clinic we always complete a course of any of the arsphenamin products before beginning a course of mercury. We can see no advantage of the mixed plan of 
administration, and believe that one has less control of either drug when they are given together. Furthermore, in case of ill effect, it is difficult accurately to lay the blame.

Concerning reactions: There is apparently no reaction due to silver arsphenamin which is peculiar to that drug and has not been noticed with any of the arsphenamin group, with the possible exception of argyria, which we shall discuss later.

Angioneurotic symptoms pass off rapidly. Many observers think that this type of disturbance is due to too large an initial dose, a too concentrated solution or too rapid injection. All of this may be avoided by a diluted small initial dose, slowly injected.

Fever is noted after the first injection in florid syphilis, as with other members of the arsphenamin group.

Cutaneous manifestations, if urticarial, pass off rapidly. If the manifestations are exanthematous, they are a warning of intolerance, and should be a positive indication for cessation of arsphenamin therapy, at least for a long period (three to six months) ; arsphenamin should be resumed only with the greatest caution. Riecke's case of death is an example-in our opinion-of not heeding a distinct warning by the organism against further arsenic. In our experience with exfoliative dermatitis following any of the arsphenamins we noticed a decided intolerance. One patient who developed a severe dermatitis after three doses of neo-arsphenamin $(0.6 \mathrm{gm}$.) at weekly intervals had a decided exanthem from $0.06 \mathrm{gm}$. given four months later, with complete rest from treatment in the interim.

Syncope, collapse, headache, weakness, nausea and vomiting is the type of reaction which we used to see frequently when we first began using the American made arsphenamins. We noted this type of reaction almost constantly after using certain control numbers. They were promptly discarded as toxic products. Possibly this type of reaction, when noted after the use of silver arsphenamin, was due to toxic chemical by-products which unavoidably occurred in early manufacture.

Icterus is a dangerous complication and requires a careful diagnosis as to cause. Is it due to the drug or to syphilis? Few observers lay much stress on the occurrence of icterus after the use of silver arsphenamin.

Thrombophlebitis was not recorded by any observer.

No authentic case of argyria has been reported! Lochte's report is unfortunate. He did not see the case himself - the case was related to him by a "nature-healer" who did not treat the woman, but who had sent her to a "specialist." She had previously received neo-arsphenamin therapy. During her course of silver arsphenamin she developed icterus, but in spite of this, the treatment was continued, 
and if the dates in the report are accurate, she received twelve doses of silver arsphenamin in less than a month's time. Kolle distinctly advises against more than $2.0 \mathrm{gm}$. in one month. Von Notthaft states that he has continued a course of silver arsphenamin for over six months with- . out ill effect. If argyria were a common danger, one should expect to hear of it in the practice of a man who believes in continuous prolonged silver arsphenamin therapy. Lochte, in his report, suggests that the woman may have had a melanosis due to arsenic, but unfortunately she was not examined by one competent to decide.

Hemorrhagic encephalitis is reported once, but does not differ from similar cases following arsphenamin treatments.

In conclusion, we must repeat that we believe silver arsphenamin is a drug which has a marked effect on the clinical manifestations of syphilis, when administered in smaller doses than is the custom with the other arsphenamins. Whether the effect is more profound and sterilization more thorough will require a longer period of observation to determine. Immediate reactions are about the same as with the other arsphenamins, and it is too early to speak with certainty of remote dangers.

One must constantly bear in mind that silver arsphenamin is a more complex salt than any of the other arsphenamins, and the physician must be on the alert for the slightest sign of intolerance. Its superiority over the other members of the group certainly is not so marked that a patient should in any way be jeopardized in order to receive this drug in preference to the other arsphenamin products.

Although the drug is highly recommended by neurologists, nothing conclusive has been published indicating a selective action on neurosyphilis. It may be that the future treatment of syphilis will call for courses of the various arsphenamin products, each having its relative chronologic position. ${ }^{44}$

707 Donaldson Building.

44. In addition to the references given, the following may be of interest: Parounagian, M.: Preliminary Report of Silver Arsphenamin, Arch. of Dermat. \& Syph. 3:333, (March) 1921.

Goodman, Herman: Silver Arsphenamin: Personal Experiences with the German Product, Urol. \& Cutan. Rev. 25:128, (March) 1921.

Walson, C. M.: Silver Salvarsan in the Treatment of Syphilis, Am. J. Med. Sc. 161:418 (March), 1921. 